\title{
Potential Products from Tropical Algae and Seaweeds, especially with Reference to Malaysia
}

\author{
Siew-Moi Phang
}

Institute of Biological Sciences \& Institute of Ocean \& Earth Sciences, University of Malaya *phang@um.edu.my (Corresponding author); phone: +603-79674610; fax: +603-79676994; (Website: http://umalgae.atspace.com)

Received on $11^{\text {th }}$ May 2010, accepted by $22^{\text {nd }}$ July 2010

\begin{abstract}
Global production and utilization of algae is a multi-billion dollar industry. There is a diversity of tropical algae and seaweeds which have yet to be fully explored for commercial products. Potential products include nutraceuticals, cosmeceuticals, feed, biopharmaceuticals, phycocolloids, horticultural aids and biofuels. Native, indigenious species should be used for industrial applications as introduced species may become invasives and cause environmental and biodiversity problems. Issues to be addressed in the development of an algae/seaweed industry include: species selection, mass-production system (photobioreactor versus open systems), productivity \& product yields, harvesting, and downstream processing. To make the commercialization cost-effective, the approach of 'multi-strategies coupled with multi-products' is essential.
\end{abstract}

ABSTRAK Penghasilan dan penggunaan alga merupakan industri yang bernilai berjutaan ringgit/dolar. Pelbagai sumber alga dan rumpair laut tropika masih belum digunakan dengan sepenuhnya sebagai produk komersial. Produk berpotensi termasuklah nutraseutikal, kosmeseutikal, makanan haiwan, biofarmaseutikal, fikokoloid, bahan hortikultur dan biofuel. Spesies-spesies tempatan dan asli harus digunakan untuk aplikasi industri, kerana ada kemungkinan spesies asing akan menjadi invasive dan mengakibatkan masalah-masalah sekitaran dan biodiversiti. Isu-isu yang mesti ditimbangkan dalam perkembangan industri alga/rumpair laut termasuk: pemilihan spesies, sistem pengkulturan secara besar-besaran (foto-bioreaktor lawan system terbuka), produktiviti \& hasil, penuaian, serta pemprosesan downstream. Pendekatan 'multi-strategi bersama multi-hasil' pasti diikuti supaya proses pengkomersilan menjadi kos-efektif.

(Keywords: Algae, seaweeds, products, issues, commercialization)

\section{INTRODUCTION}

Algae are photosynthetic organisms, often referred to as the 'lower plants' due to their simple structures and reproductive methods. Algae range from microscopic (microalgae, phytoplankton) to macroscopic (seaweeds) species, inhabiting terrestrial, freshwater, brackishwater and marine habitats. Algae are generally classified according to various criteria, the most important being type of pigment. There is an estimated 160,000 to $1,200,000$ species of algae with about 43,000 species described (Kasai et al., 2005). Global production and utilization of algae is a multi-billion dollar industry.

However more than $99 \%$ of commercial algae biomass produced worldwide are seaweeds; only about 10,000 tonnes per year is of microalgae (Benneman, Algae World Conference, Singapore, 2008). Only few microalgae species (Chlorella, Spirulina, Dunaliella, Haematococcus, Nannochloropsis) are commercially produced, mainly for health food supplements, pigments and aquaculture feed. However in recent years, interest in using microalgae as sources of biofuel has been tremendous, with inventors of massculture systems (photobioreactors) benefiting from this. Seaweeds are marine macroalgae classified into the Chlorophyta (green seaweeds), Rhodophyta (red seaweeds) and Phaeophyta (brown seaweeds).

The seaweed industry has an annual global value of US\$5.5-6 billion and is used mainly for:

i) Food : US\$ 5 billion; ii) phycocolloids (hydrocolloids); iii) fertilizer iv) animal feed additives; v) cosmetics, medicines. The industries use $7.5-8$ million tonnes wet seaweed annually, harvested from wild populations or from cultivation. About 35 countries carry out cultivation; eg. China, Japan, Korea, Philippines, Indonesia, Chile, Norway. The main consumers are Japan, China, Korea (food); Denmark, France, Japan, Norway, Spain, UK, USA (industry). 94\% seaweeds produced are used as food, Laminaria japonica (kombu, Undaria pinnatifida (wakame, Porphyra (nori), Hizikia fusiformis (hiziki), Caulerpa (sea grapes), Monostroma (hirohanahitoegusa). This brings in the highest revenue per tonne basis: Porphyra : US\$ 16,000 per dry 
tonne; Laminaria : US\$2,800 per dry tonne; Undaria : US\$ 6,900 per dry tonne

About one million tonnes wet seaweeds are used per year for production of the phycocolloids:

i) agar (US\$ 132 million); 180,000 tonnes DW seaweeds yielding 30,000 tonnes agar

ii) alginate (US\$ 13 million) 500,000 tonnes DW seaweeds yielding 18,000 tonnes alginic acid

iii) carrageenan (US\$ 240 million); 200,000 tonnes DW seaweeds yielding 15,000 tonnes carrageenan.

Other seaweed products include seaweed meal, animal feed additives, fertilizers, liquid seaweed extracts, cosmetics and traditional medicine.

Commercialisation of the algae and seaweed resources in the Tropics has not been lucrative for the local populations as they are mainly involved in the upstream activities like cultivation, harvesting and minimal processing. The raw or semi-refined materials are exported to the developed countries for final processing with many-fold increase in profits.

In Southeast Asia, only Thailand (Spirulina production in Bangkok (which ceased operation lately) and Chiengmai; Myanmar (Spirulina); and perhaps Vietnam and the Philippines, have largescale algae farms and small factories. The Spirulina is used for health food, animal feed and exported for other uses such as colourants, cosmetic supplements.

Seaweed cultivation started in the Philippines, then spread to Malaysia, Indonesia, Thailand,Vietnam, Cambodia and to India. The tropical seaweeds in commercial production include the Eucheuma, Kappaphycus , Caulerpa and Gracilaria (Phang, 2006) (See Figure 1). These seaweeds are produced for carrageenan, agar and as food. In Malaysia, seaweed (Eucheuma and Kappaphycus) production in Sabah increased from an average or 4,000 tonnes per year to almost 9,000 tonnes in 2007 (Sabah Dept. Fisheries, 2008).

At the current selling price of about RM4 per kg (pers comm. Dr. Gan, Omnigel), this could generate an income of RM 36 million (US10 million). There are plans to increase the seaweed production in Sabah to 125,000 tonnes per year (Sabah Dept. Fisheries, 2008). There are three factories in Sabah; two producing semi-refined carrageenan and one producing refined carrageenan. In Indonesia, Eucheuma and Kappaphycus farming is gaining popularity while some Gracilaria is also farmed.

Recently Gelidium was introduced and cultivated in Lombok for the production of pulp (for paper) and agar (You, APAC'09, Kuala Lumpur 2009). Algae and seaweeds are photosynthetic and require mainly sunlight, carbon dioxide, water and nutrients for mass production.

Sunshine and carbon dioxide are freely available in the tropics, water especially seawater is not lacking and nutrients especially that found in the abundant agroindustrial wastewaters is practically free for the taking. Therefore there is great potential for exploiting the tropical areas for production of algae and seaweeds.

\section{ALGAE AND SEAWEED RESOURCES IN MALAYSIA}

The microalgae resources are little known. Of about 43,000 species of microalgae described, $14 \%$ are maintained in the world's 20 major culture collections (Kasai et al., 2005). In Southeast Asia, collections are rare and restricted to specialty collections. In Malaysia, the University of Malaya Algae Culture Collection (UMACC) comprises more than 150 strains of both freshwater and marine species and polar species as well (Phang \& Chu, 1999, 2004).

The National Institute of Environmental Studies (NIES), Japan has about 1600 strains, the Provasoli-Guillard National Centre for Culture of Marine Phytoplankton (CCMP), USA has 1837 strains and CSIRO, Tasmania has about 800 strains. These Culture Collections service the researchers as well as industries by supplying strains for research; identification; and the CCMP can also generate large volume cultures if requested.

More than 386 taxa of marine algae (seaweeds) are found in Malaysian waters; Chlorophyta: 13 families, 102 taxa; Rhodophyta: 27 families, 182 taxa; Phaeophyta: 8 families, 85 taxa; and Cyanophyta: 8 families, 17 taxa (Phang 2006, Phang et al., 2007). They are found in various habitats ranging from rocky shores, coral reefs, sandy shores, mudflats, mangroves, to estuaries.

A Seaweed and Seagrasses Herbarium has been established at the University of Malaya. It houses more than 9,000 specimens and supports the biodiversity, systematics, phylogenetics, ecology and biotechnology research in the university. It is also the main reference centre for the identification and systematics studies of Malaysian and tropical seaweeds in the country.

This herbarium supports the activities of the Consortium of Southeast Asian Seaweed Taxonomy (SEASTAX) under the auspices of the Asian-Pacific Phycological Association (APPA). Research on the taxonomy, systematics and phylogenetics of the Malaysian seaweeds have 
been published by the University of Malaya Algae Research Group (see References below). The Malaysian seaweed resources have also been

(a)

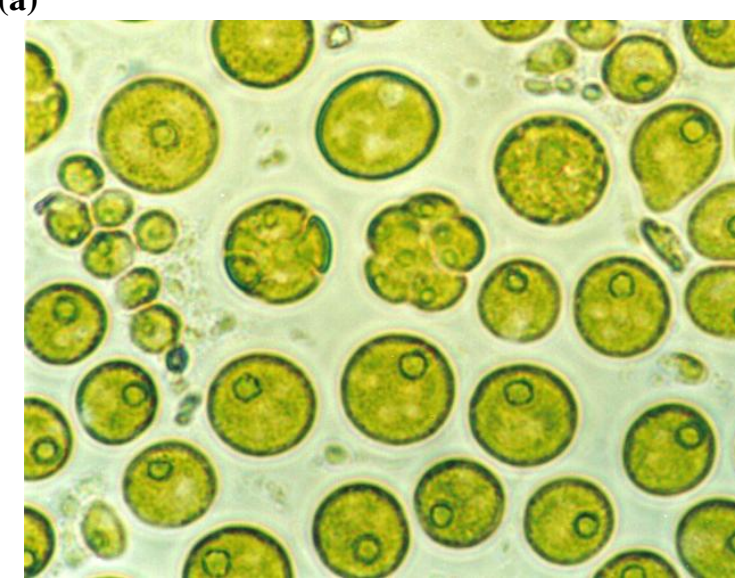

(c)

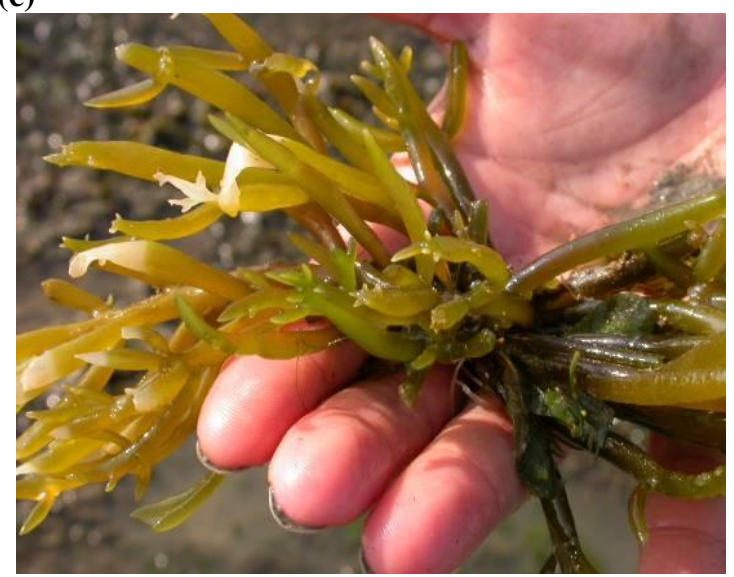

(e)

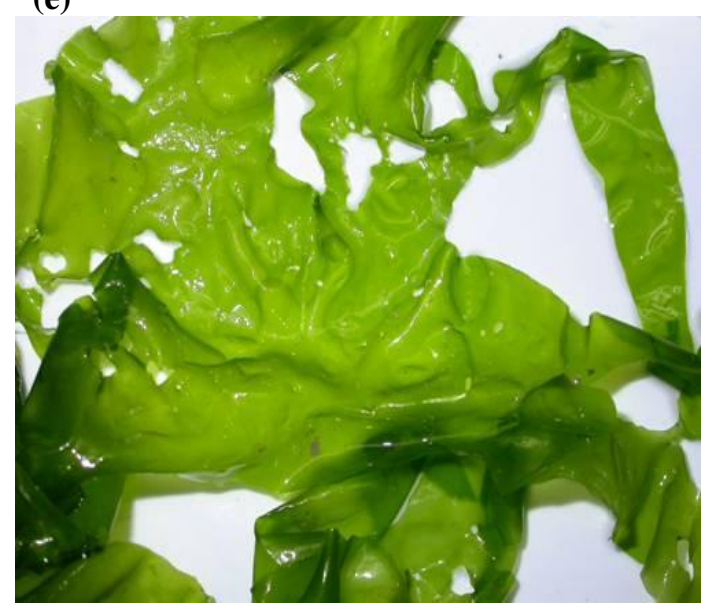

organized into a database as well as mapped using GIS (Du et al., 2008).

(b)

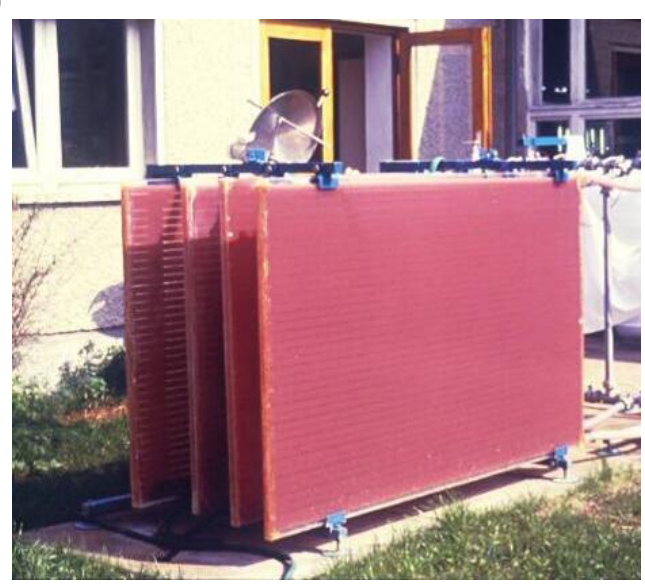

(d)

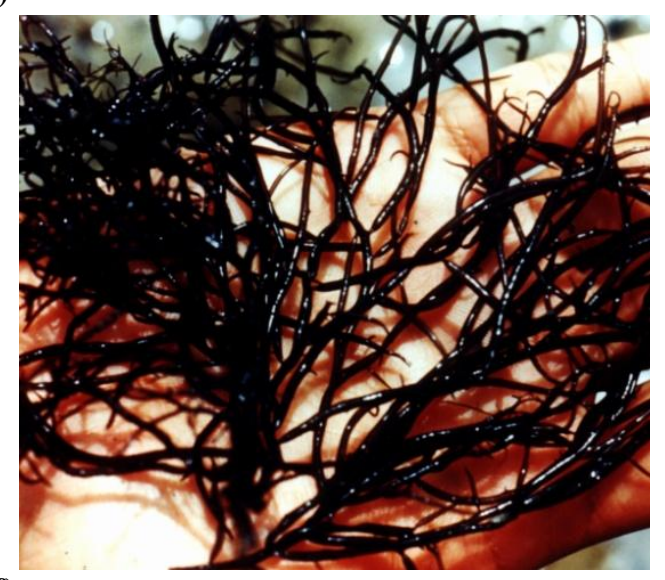

(f)

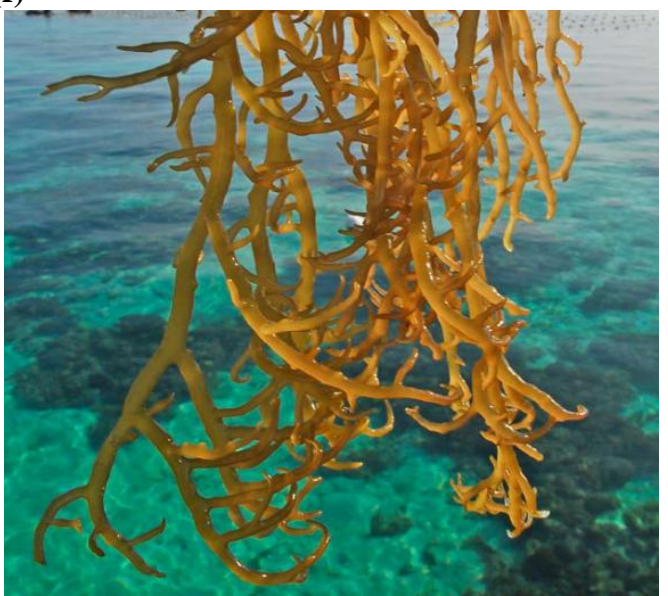

Figure 1: (a) A lipid-producing green microalgae. (b) Flat-plate photobioreactor mass-culturing Porphyridium for the pigment phycoerythrin in Professor Otto Pulz's laboratory in Germany. (c) Ulva used as a salad and has potential for producing bioethanol (d) Kappaphycus, a source of carrageenan. (e) Gracilaria an agar-producing red seaweed. (f) Solieria, an agar-producing red seaweed which also makes a tasty salad. 


\section{POTENTIAL UTILISATION OF TROPICAL ALGAE AND SEAWEED RESOURCES, WITH REFERENCE TO MALAYSIA}

Latitudinal differences result in the evolution of variation in genera, species, or strains amongst the algae and seaweed resources. Some taxa are pantropical; viz. the ubiquitous Chlorella; Caulerpa; Codium; Cladophora; Acetabularia. In the industrial application of algae and seaweeds, it is advisable to use local, native species rather than introduce alien strains even though the latter provides a much shorter but not necessarily more efficient route.

Alien or introduced strains may not adapt to the local environment and may be more susceptible to disease and parasitism; some may even end up as threats to the local endemic flora by invading and dominating local habitats, as shown by the invasive Caulerpa taxifolia which was accidentally transported from the east to Europe. Native species are already adapted to ambient conditions and it only takes the identification of suitable strains for the targeted product.

While a wide range of products have already been identified and are in current commercial application, this paper will only focus on the products and processes/services that may be of potential to the tropical region especially Malaysia (Table 1). The following products are not in order of priority.

Table 1: Products from microalgae and seaweeds.

\begin{tabular}{|c|c|c|c|}
\hline & Product/Process/Service & Microalgae & Seaweeds \\
\hline 1 & Food/Nutraceuticals & $\begin{array}{l}\text { Nutraceuticals (PUFA, } \\
\text { carotenoids, anti-oxidants), } \\
\text { detoxicants, colourants }\end{array}$ & $\begin{array}{l}\text { Alga-oligosaccharides (soluble } \\
\text { agar, alginate, fucoidans) }\end{array}$ \\
\hline 2 & Feed & Feed enhancers, colourants & Seaweed meal \\
\hline 3 & Cosmeceuticals & $\begin{array}{l}\text { Anti-oxidant, suncare products, } \\
\text { etc. }\end{array}$ & $\begin{array}{l}\text { Excipients, emulsifiers, anti- } \\
\text { cellulite, anti-aging, etc. }\end{array}$ \\
\hline 4 & Biopharmaceuticals & $\begin{array}{l}\text { Anti-viral, Anti-cancer, Algal } \\
\text { vaccines, etc. }\end{array}$ & $\begin{array}{l}\text { Photosensitisers in Photo- } \\
\text { dynamic therapy, microbiocide } \\
\text { (Carraguard) }\end{array}$ \\
\hline 5 & Industrial colloids & Algal polysaccharides & Agar, agarose, carrageenan \\
\hline 6 & Horticultural aids & Fertiliser & $\begin{array}{l}\text { Fertiliser, } \\
\text { soil conditioners, foliar sprays } \\
\text { (growth hormones) }\end{array}$ \\
\hline 7 & Renewable Energy (Biofuel) & Methane, Biodiesel, Hydrogen & Methane, Methanol, Ethanol \\
\hline 8 & $\begin{array}{l}\text { Climate Change } \\
\text { Management }\end{array}$ & $\begin{array}{l}\mathrm{CO}_{2} \text { Reduction/Global warming } \\
\text { management }\end{array}$ & $\begin{array}{l}\mathrm{CO}_{2} \text { Reduction/Global } \\
\text { warming management }\end{array}$ \\
\hline 9 & $\begin{array}{l}\text { Bioremediation/Nutrient } \\
\text { Removal }\end{array}$ & $\begin{array}{l}\text { Waste bioremediation, nutrient } \\
\text { recovery }\end{array}$ & $\begin{array}{l}\text { Waste bioremediation, nutrient } \\
\text { recovery }\end{array}$ \\
\hline 10 & Novel useful genes & $\begin{array}{l}\text { Improved strains; new products } \\
\text { from genetic manipulation }\end{array}$ & $\begin{array}{l}\text { Improved strains; new products } \\
\text { from genetic manipulation }\end{array}$ \\
\hline 11 & $\begin{array}{l}\text { As living bioreactors for novel } \\
\text { products and services }\end{array}$ & Algal vaccines & Vaccines \\
\hline
\end{tabular}


The nutraceutical and cosmeceutical, market is big and there is great potential for algae and seaweeds to capture a good share of this market. The nutraceutical industry is worth US\$11.7billion. "Global demand for nutraceutical ingredients will grow 5.8 percent annually through 2010. Best prospects include probiotics, soy additives, lycopene, lutein, sterolbased additives, green tea, glucosamine and chondroitin, and coenzyme Q10. China and India will be the fastest growing markets, while the US will remain the largest" (www.freedoniagroupcom, 2008). Algae can supply lycopene, lutein, sterols. The cosmeceutical market is worth US $\$ 5.8$ billion. "Demand for cosmeceuticals in the US will increase 7.4 percent annually through 2012, driven by an aging population seeking to maintain youthful appearance. Antioxidants, botanicals and enzymes are best opportunities, with injectables and skin care products having fastest growth" (www.freedoniagroupcom, 2008).

The Renewable Energy Market Opportunity (2005-2015) is as follows: Biofuels - US\$ 15.7B to $52.5 \mathrm{~B}$; Solar power - US\$11.2B to $51.1 \mathrm{~B}$; Wind power - US $\$ 11.8 \mathrm{~B}$ to $48.5 \mathrm{~B}$. In Malaysia the transport sector takes up $38 \%$ of total energy consumption; biofuels can lighten this demand from fossil fuel. Using genetically-modified algae, a US company claimed to be able to produce 4000 gall/ac/yr of crude diesel from 40 tonnes/ac/yr biomass (presented at ISAP, Galway, 2008).

\section{STRATEGY}

Of the many potential products listed above, some may be near commercialization, while others still require sound, honest scientific work. Projections on productivity are extrapolated on small-scale studies, therefore, as an example, while it is possible to produce biodiesel from microalgae, it is as yet not economical. Issues to be addressed include: species selection, massproduction system (photobioreactor versus open systems), productivity \& oil yields, harvesting, oil extraction.

These same issues apply to most other products. To make the commercialization cost-effective, the approach of 'multi-strategies coupled with multi-products' is essential. The search for useful genes through genomics research (Ho et al., 2009; Teo et al., 2009) and production of transformed seaweeds (Gan et al., 2003; Gan \& Phang, 2006) with higher productivities and novel products is another important area for research. Production costs can be reduced by integrating algae/seaweed biomass production with wastewater bioremediation or even carbon sequestration, eg. aquaculture effluents (Habib et al. 2003; Phang et al. 2000; Phang et al., 1996). Combined with environmental considerations where Life-Cycle Assesments be made a necessary component of product development, we may well be on the road to having a sustainable, profitable, green Algae-Seaweed Industry in Malaysia.

\section{ACKNOWLEDGEMENTS}

The author wishes to thank MARDI and in particular Dr. Tan Swee Lian, for permission to publish this paper which was presented at the National Conference on New Crops and Bioresources 2009, Seremban, Malaysia.

\section{REFERENCES}

1. Chan C-X, Ho CL \& Phang SM. 2006 Trends in seaweed research. Trends Plant Sci.11(4): 165-166

2. Chu WL, See YC and Phang SM. 2009. Use of immobilised Chlorella vulgaris for the removal of colour from textile dyes. J. Appl. Phycol. 21:641-648. DOI 10.1007/s10811008-9396-3

3. Chu WL, Norazmi Mohamed \& Phang SM. 2003. Fatty-acid composition of some Malaysian seaweeds. Malaysian J. Science 22(2): 21-27

4. Chu WL, Afnani Alwi \& Phang SM. 2002. Phycoerythrin production by a marine Oscillatoria (Cyanophyta). Mal. J. Science 21: 67-73

5. Chu WL, Phang SM, Miyazaki K \& Tosu T. 2002. Influence of irradiance and inoculum density on the pigmentation of Spirulina platensis. Asia-Pacific Journal of Molecular Biology and Biotechnology 10(2): 109-117

6. Chu WL, Phang SM, \& Goh SH. 1994. Studies on the production of useful chemicals, especially fatty acids in the marine diatom Nitzschia conspicua Grunow. Hydrobiologia 285: 33-40

7. Du HL, Ooi JLS, Fauzi R and Phang SM. 2008. Spatial patterns of seaweed distribution in Malaysia using GIS. (eds. Liu et al.) Proc.SPIE vol. 7145:71452H-1 to $71452 \mathrm{H}-9$. (doi:10.1117/12.813073)

8. Gan SY, Song Qin, Rofina Yasmin Othman, Daozhan Yu, Phang SM. 2003. Transient expression of lac $\mathrm{Z}$ in particle bombarded Gracilaria changii (Gracilariales, Rhodophyta). J. appl. Phycology 15:351-353

9. Gan SY \& Phang SM. 2006. Seaweeds as bioreactors for valuable biopharmaceuticals. In: Phang SM, Azahar Hussin, Chong VC, Mary George, Siti Aisyah Alias \& Ho SC (eds) Innovations and Technologies in Oceanography for Sustainable Development. 
University of Malaya maritime Research Centre. p. 55-72.

10. Gan SY, Rofina Yasmin Othman, Qin S \& Phang SM. 2006. Crop improvement in seaweed cultivation. In: Phang et al. (eds) Advances in Seaweed Cultivation and Utilisation in Asia. University of Malaya Maritime Research Center Publication. p. 81104.

11. Habib M.A.B., F. M. Yusoff, S. M. Phang, M. and S. Mohmed, 2003. Growth and Nutritional Values of Moina micrura Fed on Chlorella vulgaris Grown in Digested Palm Oil Mill Effluent. Asian Fisheries Science 16 (2003): 107-119

12. Habib MAB, Yusoff FM, Phang SM \& Ang KJ. 1997. Nutritional value of chironomid larvae grown in palm oil mill effluent and algal culture. Aquaculture 158: 95-105

13. Ho CL \& Phang SM. 2006. Seaweed functional genomic research - the present and the future perspectives. In: Phang et al. (eds) Advances in Seaweed Cultivation and Utilisation in Asia. University of Malaya Maritime Research Center Publication. p. 143-152

14. Ho CL, Teoh S, Teo SS, Rahim RA and Phang SM (2009). Profiling the Transcriptome of Gracilaria changii (Rhodophyta) in Response to Light Deprivation. Mar Biotechnol 11:513-519 DOI 10.1007/s10126-008-9166-x

15. Kasai F, Kaya K. \& Watanabe MM. 2005. Algal Culture Collections and the Environment. Tokai University Press. 248p.

16. Kawaguchi S, Kato A, Masuda M, Kogame K \& Phang SM. 2002. Taxonomic notes on marine algae from Malaysia VII. Five species of Rhodophyceae, with the description of Lomentaria gracillima sp. nov. Botanica Marina 45(6): 536-547

17. Lai P J, Chu WL, Naidu R, Khoo ASB, Kok YY, Shar MM, Ling SN, Mak JW, Lim KC, Balraj P and Phang SM. 2008. Antiproliferative Activity of Microalgal Extracts on Nasopharyngeal Carcinoma (NPC) Cells. Malaysian J. Science 27 (2): 19 -31 .

18. Lim PE \& Phang SM. 2004. Gracilaria species (Gracilariales, Rhodophyta) of Malaysia including two new records. Mal. J. Sci. 23(2): 71-80

19. Phang SM \& Chu WL. 2004. The University of Malaya Algae Culture Collection (UMACC) and potential applications of a unique Chlorella from the collection. Jap. J. Phycol. 52: 221-224

20. Masuda M, Uwai S, Kogame K, Kawaguchi S \& Phang SM. 2003. Taxonomic notes on marine algae of Malaysia X. Four species of Dasya (Rhodophyceae) with the descriptions of Dasya longifila sp. nov. and D. malaccensis sp. nov. Botanica Marina 46: 243-255.

21. Masuda M, Abe T, Kogame K, Kawaguchi S, Phang SM, Daitoh M, Sakai T, Takahashi Y \& Suzuki M. 2002. Taxonomic notes on marine algae of Malaysia VIII. Three species of Laurencia (Rhodophyceae). Botanica Marina 45(6): 571-579

22. Phang SM. 2006 Seaweed Resources in Malaysia: Current status and future prospects. Aquatic Ecosystem Health \& Management 9(2): 185-202

23. Phang SM, Miah S, Yeoh BG \& Hashim MA. 2000 Spirulina production in digested sago starch wastewater. J. appl. Phycol.12:395-400

24. Phang SM, Shafeei Shaharuddin, Hashim Noraishah \& Sasekumar A. 1996. Studies on Gracilaria changii (Gracilariales, Rhodophyta) from Malaysian mangroves. Hydrobiologia 327: 347-352

25. Phang SM, Miah S, Yeoh BG \& Hashim MA. 2000 Spirulina production in digested sago starch wastewater. J. appl. Phycol.12:395-400

26. Phang SM, Shafeei Shaharuddin, Hashim Noraishah \& Sasekumar A. 1996. Studies on Gracilaria changii (Gracilariales, Rhodophyta) from Malaysian mangroves. Hydrobiologia 327: 347-352

27. Phang SM, Lewmanomont K, Lim PE (eds).2008. Taxonomy of Southeast Asian Seaweeds. Institute of Ocean and Earth Sciences, University of Malaya Monograph Series 2. ISBN: 978-967-5148-13-2.

28. Phang SM, Critchley AT \& Ang PO Jr. 2006. Advances in Seaweed Cultivation and Utilisation in Asia. 177 pp. ISBN 983-957630-5

29. Phang SM \& Chu WL .1999.University of Malaya Algae Culture Collection. Catalogue of Strains. Institute of Postgraduate Studies and Research, University of Malaya.77pp. ISBN 983-9578-25-9

30. Phang SM \& Chu WL. 2005. The University of Malaya Algae Culture Collection:19872005. In: Kasai $\mathrm{F}$ et al. (eds) Algae Culture Collections and the Environment. Tokai University Press. p. 13-20

31. Phang SM. 1998. The Seaweed Resources of Malaysia. In: Seaweed Resources of the World. (eds Critchley A \& Ohno M). JICA publication p.79-91

32. Tani M, Yamagishi Y, Masuda M, Kogame K, Kawaguchi S \& Phang SM. 2003. Taxonomic notes on marine algae of Malaysia IX. Four species of Rhodophyceae, with the description of Chondria deciduas sp.nov. Botanica Marina 46: 24-35 
33. Teo SS, Ho CL, Teoh S, Raha Abdul Rahim \& Phang SM (2009). Transcriptomic analysis of Gracilaria changii (Rhodophyta) in response to hyper- and hypo-osmotic stresses. J. Phycol. 45. DOI: 10.1111/j.15298817.2009.00724.x (In press)

34. Teo SS, Ho CL, Teoh S, Lee WW, Tee JM, Raha Abdul Rahim \& Phang SM (2007) Analyses of expressed sequence tags (ESTs) from an agarophyte Gracilaria changii (Gracilariales, Rhodophyta). Eur. J. Phycol. 42(1): 41-46

35. Wong TK-M, Ho CL, Lee WW, Raha Abd, Rahim \& Phang SM. 2007. Analyses of expressed sequence tags from Sargassum binder (Phaeophyta). J. Phycol. 43:528-534

36. Varaippan CS \& Phang SM. 2005 Morphology and Halochamegrene Metabolite Content of Laurencia majuscule (Rhodomelaceae, Ceramiales) from the Spratly Islands. Malaysian J. Science 24(2): 29-36

37. Vairappan CS, Ang MY, Ong CY \& Phang SM. 2004. Biologically active polybrominated indoles in the red alga Laurencia similis from the coastal waters of Sabah (Rhodomelaceae, Ceramiales). Mal. J. Sci. 23 (2): 119-126

38. Varaippan CS \& Phang SM. 2005 Morphology and Halochamegrene Metabolite Content of Laurencia majuscule (Rhodomelaceae, Ceramiales) from the Spratly Islands. Malaysian J. Science 24(2): 29-36

39. Vairappan CS, Ang MY, Ong CY \& Phang SM. 2004. Biologically active polybrominated indoles in the red alga Laurencia similis from the coastal waters of Sabah (Rhodomelaceae, Ceramiales). Mal. J. Sci. 23 (2): 119-126

40. Yamagishi Y, Masuda M, Abe T, Uwai S, Kogame K, Kawaguchi S \& Phang SM. 2003. Taxonomic Notes on Marine Algae from Malaysia XI. Four species of Rhodophyceae. Botanica Marina 46: 534-547

41. Zhang DH, Lee YK, Ng ML \& Phang SM. 1997. Composition and accumulation of secondary carotenoids in Chlorococcum sp. J. appl. Phycol. 9(2): 147-155 